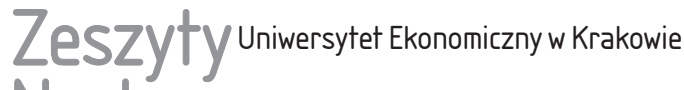 Naukowe
}

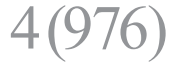

ISSN 1898-6447

e-ISSN 2545-3238

Zesz. Nauk. UEK, 2018; 4 (976): 183-200

https://doi.org/10.15678/ZNUEK.2018.0976.0411

Aleksander R. Mercik

\section{Miara ryzyka estymacji parametrów modelu VaR}

\section{Streszczenie}

Obecnie wartość zagrożona jest jedną z najpopularniejszych miar ryzyka finansowego. W literaturze przedmiotu można spotkać się z wieloma podejściami do walidacji modeli wartości zagrożonej. W praktyce oprócz przeprowadzania testów ex post należy zweryfikować model w momencie jego tworzenia i wtedy można dokonać tzw. analizy ryzyka modelu. W dziedzinie finansów szczególnie istotne jest ryzyko estymacji modelu ze względu na ograniczoną liczbę danych historycznych, które są dostępne do estymacji parametrów. Celem artykułu jest zaproponowanie miary ryzyka estymacji parametrów modelu VaR opartej na przedziałowej estymacji wartości zagrożonej.

Słowa kluczowe: wartość zagrożona, estymacja przedziałowa, ryzyko modelu, ryzyko estymacji parametrów modelu.

Klasyfikacja JEL: G32.

\section{Wprowadzenie}

W procesie zarządzania ryzykiem konieczne jest weryfikowanie wykorzystywanych modeli, zarówno przed ich wdrożeniem, jak i podczas ich regularnego stosowania. Przeprowadzanie kontroli w tym zakresie pozwala na zidentyfikowanie modeli wymagających poprawienia lub wprowadzenia zmiany, czyli takich, które w niewystarczający sposób odwzorowują zjawiska zachodzące na rynkach

Aleksander R. Mercik, Uniwersytet Ekonomiczny we Wrocławiu, Wydział Zarządzania, Informatyki i Finansów, Katedra Inwestycji Finansowych i Zarządzania Ryzykiem, ul. Komandorska 118/120, 53-345 Wrocław, e-mail: aleksander.mercik@ue.wroc.pl 
finansowych. W teorii opracowano wiele narzędzi umożliwiających odrzucenie nieodpowiednich metod. W praktyce modele powinny nie tylko odzwierciedlać rzeczywiste zjawiska, ale również spełniać dodatkowe warunki. Po pierwsze, powinny mieć możliwie jasną interpretację ekonomiczną, aby zminimalizować ryzyko zastosowania ich w sposób nieadekwatny do budowy. Po drugie, nie powinny być bardziej złożone, niż jest to potrzebne, np. nie powinny posiadać zbyt dużej liczby parametrów. Po trzecie, parametry tych modeli nie mogą być zbyt trudne do estymacji - dużo trudniej w praktyce zastosować estymację bayesowską niż metodę maksymalizacji wartości funkcji wiarygodności. Zastosowanie tych metod wymaga wykonywania symulacji w zaawansowanych środowiskach obliczeniowych, nie zawsze dostępnych w firmach, które stają przed problemem zarządzania ryzykiem rynkowym. Drugi i trzeci warunek służą ograniczeniu ryzyka estymacji parametrów. Oba podrodzaje ryzyka, tzn. ryzyko błędnej specyfikacji modelu oraz ryzyko estymacji, składają się na tzw. ryzyko modelu (Jajuga 2013). Im interpretacja modelu jest mniej jasna, im więcej ma on parametrów albo im trudniej dostępne są dane potrzebne do ich estymacji, tym ryzyko modelu jest wyższe. Celem artykułu jest zaproponowanie miary ryzyka estymacji parametrów modelu VaR w oparciu o przedziałową estymację wartości zagrożonej oraz z wykorzystaniem koncepcji testu Kupca.

\section{Ryzyko modelu}

Jakość modeli służących do pomiaru ryzyka finansowego jest prawdopodobnie jednym z najważniejszych elementów modelu biznesowego wielu dużych przedsiębiorstw z branży finansowej. W skrajnych przypadkach może ona przesądzić o przetrwaniu lub bankructwie danego podmiotu. $Z$ tego powodu metodyka weryfikacji i selekcji stosowanych metod jest szczególnie istotna. Warto zauważyć, że przydatność modeli stosowanych w modelowaniu zjawisk ekonomicznych zależy od stopnia, w jakim przybliżają one rzeczywiste zjawisko (Jajuga 2013). $\mathrm{W}$ pewnych sytuacjach przybliżenie to jest satysfakcjonujące, a w innych może prowadzić do wielu pomyłek i błędów.

Aby stwierdzić, czy dany model może być przydatnym narzędziem, należy przeprowadzić jego weryfikację ex post, czyli porównać przeszłe prognozy ze znanymi już prawdziwymi wartościami prognozowanych wielkości. Czasami jednak zachodzi potrzeba zweryfikowania modelu w momencie jego tworzenia i wtedy można dokonać tzw. analizy ryzyka modelu (Kuziak 2011). Zgodnie $\mathrm{z}$ definicją podaną we wprowadzeniu ryzyko modelu wynika z zastosowania błędnego modelu w świecie rzeczywistym. Można wyróżnić trzy podstawowe rodzaje ryzyka modeli w dziedzinie finansów: 
- ryzyko w zakresie struktury modelu,

- ryzyko estymacji parametrów modelu,

- ryzyko zastosowania modelu.

Ryzyko w zakresie struktury modelu może być związane z nieprawidłową postacią funkcyjną modelu, czyli np. nieuwzględnieniem w nim istotnych zmiennych lub dynamiki. Sprawdzenie poprawności struktury modelu polega na przeprowadzeniu analizy jakościowej. W pierwszej kolejności powinny zostać zweryfikowane założenia modelu. W wypadku wielu podstawowych modeli przyjmuje się np. założenie, że rozkład reszt jest normalny. Zasadność tego założenia można zweryfikować poprzez analizę danych historycznych. Kolejnym elementem weryfikacji może być przeprowadzenie testów wstecznych. Warto jednak podkreślić, że wiele modeli, które bardzo dobrze odzwierciedlały rzeczywistość w odniesieniu do przeszłości, daje niezadowalające rezultaty odnośnie do przyszłości. Problem ten dotyczy przede wszystkim modeli zawierających dużą liczbę parametrów. Im model jest bardziej złożony, tym łatwiej dopasować go do danych historycznych, ale jego przydatność w zakresie prognozowania przyszłych zjawisk może być znikoma.

Ryzyko estymacji parametrów modelu można zdefiniować jako możliwość błędnej estymacji parametru na skutek wybrania nieprawidłowej metody estymacji lub zastosowania źle dobranego zbioru danych. Ryzyko to w dziedzinie finansów jest szczególnie istotne, m.in. ze względu na ograniczoną liczbę danych historycznych. Oprócz skończonej długości próby błąd w oszacowaniu parametrów może wynikać również z przyjęcia nieprawidłowej metody estymacji (np. wykorzystania metody, w której nie uwzględnia się występowania obserwacji nietypowych, lub estymacji parametrów bez wzięcia pod uwagę niestacjonarności szeregów czasowych). Do oszacowania tego ryzyka można wykorzystać narzędzia ilościowe, do których należą m.in.:

- analiza wrażliwości modelu na zmiany wartości parametrów, która ma na celu określenie najbardziej istotnych elementów modelu,

- estymacja przedziału ufności dla parametru przy znanej wielkości próby.

Ryzyko zastosowania modelu dotyczy sytuacji, w której model jest wykorzystywany w innych warunkach niż te, w jakich zostały oszacowane parametry lub przeprowadzono walidację. Ocenienie tego, czy model został poprawnie zastosowany, powinno polegać na sprawdzeniu spełnienia wszystkich założeń, na których się opiera. Przykładów złego zastosowania modeli jest wiele. Szczególnie problematyczna jest sytuacja podwyższonej zmienności (np. podczas krachów na giełdach). Wiele modeli estymowanych w warunkach stabilności rynków finansowych przestaje działać prawidłowo, gdy pojawiają się obserwacje skrajne. Innym przykładem jest próba stosowania modeli finansowych stworzonych na rynkach rozwiniętych (np. modelu wyceny opcji) do wyceny instrumentów pochodnych na 
rynku wschodzącym, w wypadku którego inny jest proces zmienności, a płynność radykalnie niższa.

Warto również podkreślić, że im większa jest złożoność stosowanych modeli, tym mniejsza jest ich przejrzystość, a tym samym większe ryzyko modelu. Narzędzia statystyczne wykorzystywane na rynkach finansowych powinny być odporne na zmiany warunków rynkowych i na tyle klarowne, aby odporność tę dało się zweryfikować już w momencie tworzenia modelu. Prostota modelu jest również niezbędna do określenia założeń, na których został oparty, co umożliwia przeprowadzenie analizy ryzyka zastosowania modelu.

\section{Kwantylowe miary ryzyka i wartość zagrożona}

Spośród modeli ryzyka rynkowego szczególne znaczenie mają te, które służą do szacowania kwantylowych miar ryzyka. Są to miary oparte na kwantylach rozkładu zmiennej ryzyka. Zmienną ryzyka może być w tym przypadku stopa zwrotu z inwestycji, jej wartość albo strata wyrażona w jednostkach pieniężnych (Zarzqdzanie... 2008). Najbardziej popularną kwantylową miarą ryzyka jest wartość zagrożona (value at risk - VaR) (Jajuga 2001). Definiuje się ją jako pewien kwantyl z górnego ogona rozkładu straty wyrażonej w jednostkach pieniężnych. Jej szacowanie sprowadza się jednak do wyznaczania kwantylu z dolnego ogona rozkładu stopy zwrotu, a to najczęściej wymaga oszacowania zmienności. Do szacowania kwantylowych miar ryzyka zazwyczaj wykorzystuje się modele zmienności, tak więc istnieje ścisły związek między modelami zmienności i kwantylowymi modelami ryzyka. W większości kwantylowych modeli ryzyka model zmienności jest wręcz głównym elementem konstrukcyjnym (Doman i Doman 2009).

Obecnie wartość zagrożona (nazywana również wartością narażoną na ryzyko) jest jedną z najpopularniejszych miar ryzyka finansowego. Mimo że została pierwotnie zastosowana do pomiaru ryzyka rynkowego, to $z$ dużym powodzeniem może być używana do pomiaru innego typu ryzyka (zwłaszcza ryzyka kredytowego i operacyjnego). Pierwszą instytucją finansową, która opublikowała materiały dotyczące wartości zagrożonej, był bank J.P. Morgan (w październiku 1994 r.) $)^{1}$. Kolejne istotne opracowania poświęcone wartości zagrożonej zostały opublikowane przez RiskMetrics Group (która działała wtedy jako jednostka banku J.P. Morgan), były to: CreditMetrics ${ }^{\mathrm{TM}}$ (w kwietniu 1997 r.) oraz CorporateMetrics $^{\mathrm{TM}}$ (w kwietniu 1999 r.).

${ }^{1}$ Koncepcja wartości zagrożonej była wspierana przez Grupę Trzydziestu (G30) - międzynarodowy organ skupiający najlepszych finansistów i uczonych. 
W najprostszy sposób wartość zagrożoną można zdefiniować jako stratę wartości rynkowej (np. instrumentu finansowego, portfela, instytucji), taką że prawdopodobieństwo osiągnięcia jej lub przekroczenia w danym okresie jest równe określonemu poziomowi tolerancji (Zarzqqdzanie... 2008). Formalnie wartość zagrożoną można zapisać za pomocą następującego wzoru:

$$
P\left(W_{T} \leq W_{t}-\operatorname{VaR}\left(W_{t}, t, T, \propto\right)\right)=\propto,
$$

gdzie:

$W_{t}$ - obecna wartość inwestycji (np. instrumentu finansowego, portfela, instytucji),

$W_{T}$ - wartość inwestycji w chwili końcowej $T$,

$\alpha$ - poziom tolerancji (najczęściej $1 \%$ lub 5\%),

$\operatorname{VaR}\left(W_{t}, t, T, \propto\right)$ - wartość zagrożona obliczona w momencie początkowym $t$ dla horyzontu $T-t$ i poziomu istotności $\alpha$.

Najczęściej uwzględnianym przez banki horyzontem czasowym jest jeden dzień (Rokita 2004). Wybór tak krótkiego terminu nie jest przypadkowy. Skład portfela, dla którego dokonuje się pomiaru ryzyka, może szybko ulec zmianie, co sprawia, że estymacja wartości zagrożonej dla okresów dłuższych niż miesiąc posiada wiele ograniczeń, m.in. ze względu na trudności w zestawieniu prognozy ze zrealizowanym wynikiem (Best 2000). Inne instytucje finansowe, w wypadku których ekspozycja nie ulega tak szybko zmianie (np. fundusze inwestycyjne i przedsiębiorstwa), biorą pod uwagę okres miesięczny. Najczęściej uwzględnianymi poziomami tolerancji, zalecanymi przez instytucje nadzorujące rynek finansowy, są $1 \%$ i $5 \%$. Im poziom tolerancji jest niższy, tym wyższy jest poziom wartości zagrożonej.

\section{Klasyczne metody walidacji modeli wartości zagrożonej}

W literaturze przedmiotu opisano dwa podejścia do walidacji modeli wartości zagrożonej. Pierwsze z nich opiera się na analizie empirycznej realizacji przekroczeń VaR i zostało zaproponowane przez P.H. Kupca (1995). W metodzie tej szereg przekroczeń (failure process, hit function) można zdefiniować w następujący sposób (Piontek 2007):

$$
I_{t}=\left\{\begin{array}{l}
1, r_{t+1}<-V a R_{t} \\
0, r_{t+1} \geq-V a R_{t}
\end{array}\right.
$$

gdzie:

$r_{t+1}$ - stopa zwrotu z okresu $t+1$,

$V a R_{t}$ - wartość zagrożona w czasie $t$. 
W drugim podejściu korzysta się ze statystyk opisowych mierzących wielkość przekroczeń wartości zagrożonej. Najlepszym przykładem zastosowania tego podejścia są tzw. funkcje straty.

Najczęściej wykorzystywanym testem modelu wartości zagrożonej jest test analizujący faktyczną liczbę przekroczeń w odniesieniu do założonego poziomu tolerancji (Kupiec 1995). Test ten został opracowany, aby można było odpowiedzieć na pytanie, czy liczba strat przekraczających oszacowaną wartość zagrożoną jest zbliżona do założonego poziomu tolerancji (Dowd 2006), czyli przeprowadzając go, dokonuje się porównania empirycznego udziału przekroczeń z prawdopodobieństwem sukcesu w teoretycznym modelu niezależnych prób Bernoulliego.

Hipotezą zerową w teście jest:

$$
H_{0}: p=\hat{p}=\frac{x}{T},
$$

hipotezą alternatywną:

$$
H_{1}: p \neq \hat{p}
$$

gdzie:

$x$ - liczba przekroczeń,

$T$ - liczba wszystkich obserwacji,

$p$ - poziom tolerancji w modelu VaR.

Kryterium oceny ex post prognoz VaR sformułowano w postaci testu ilorazu wiarygodności restrykcji parametru $p$. Statystyka testowa ma postać:

$$
L R_{P O F}=-2 \ln \left(\frac{(1-p)^{T-x} p^{x}}{\left(1-\frac{x}{T}\right)^{T-x}\left(\frac{x}{T}\right)^{x}}\right) .
$$

Jest to statystyka $L R_{P O F}$ rozkład $\chi^{2} \mathrm{z}$ jednym stopniem swobody. W tabeli 1 przedstawiono minimalną i maksymalną liczbę przekroczeń dla różnych poziomów tolerancji i wielkości prób, aby model nie został odrzucony.

Tabela 1. Przedziały liczby przekroczeń dla współczynnika ufności 0,95

\begin{tabular}{|c|c|c|c|c|c|c|}
\hline \multirow{2}{*}{$\begin{array}{c}\text { Poziom tolerancji VaR } \\
(\mathrm{w} \%)\end{array}$} & \multicolumn{9}{|c|}{ Wielkość próby } \\
\cline { 2 - 7 } & \multicolumn{2}{|c|}{255} & \multicolumn{2}{|c|}{510} & \multicolumn{2}{c|}{1000} \\
\cline { 2 - 7 } & $\min$ & $\max$ & $\min$ & $\max$ & $\min$ & $\max$ \\
\hline 1,0 & 1 & 6 & 2 & 10 & 5 & 16 \\
\hline 2,5 & 3 & 11 & 7 & 20 & 16 & 35 \\
\hline 5,0 & 7 & 20 & 17 & 35 & 38 & 64 \\
\hline 7,5 & 12 & 27 & 28 & 50 & 60 & 91 \\
\hline 10,0 & 17 & 35 & 39 & 64 & 82 & 119 \\
\hline
\end{tabular}

Źródło: opracowanie własne. 


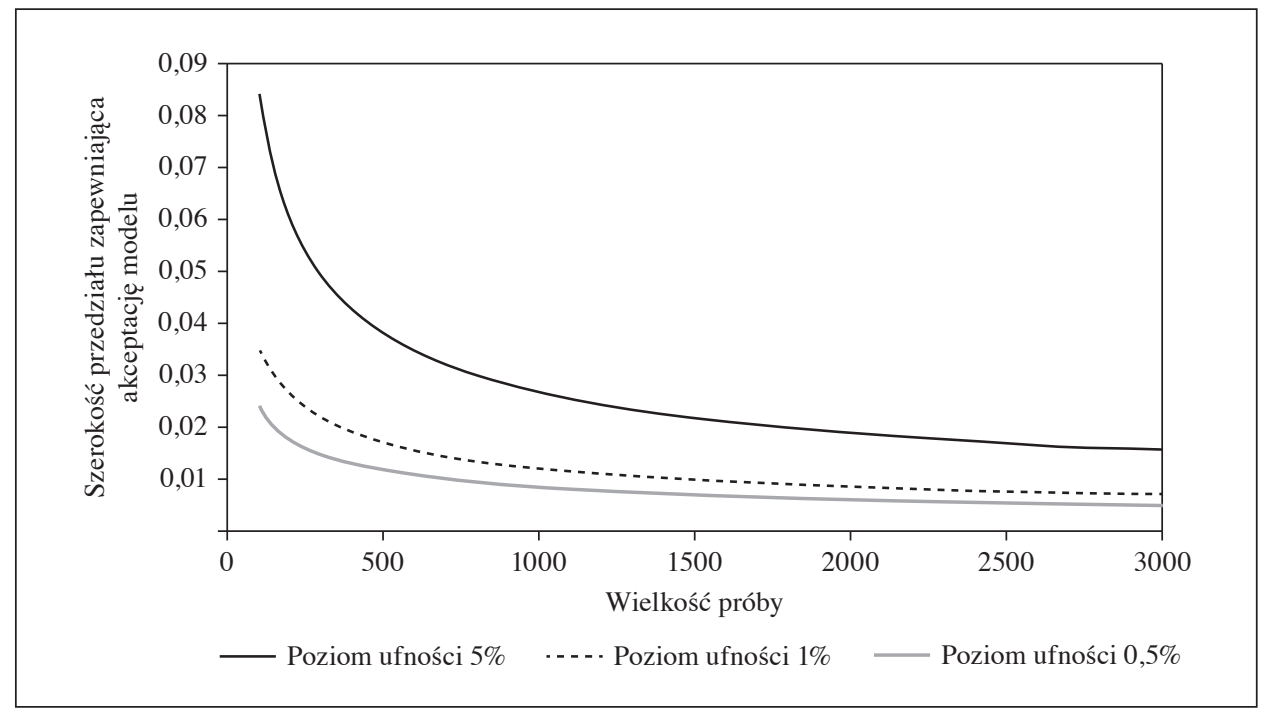

Rys. 1. Szerokość przedziału częstości występowania przekroczeń dla poszczególnych wielkości próby i współczynnik ufności, dla których nie ma powodów do odrzucenia modelu

Źródło: opracowanie własne.

Im długość szeregu przekroczeń jest większa (im większa jest próba wykorzystana do testu), tym mniejsza jest szerokość przedziału, w którym powinna się mieścić liczba przekroczeń, przy założeniu, że wybrany model prawidłowo odzwierciedla badane zjawisko. Na rys. 1 pokazano, jak w miarę zwiększania próby dla każdego z poziomów tolerancji zmniejsza się szerokość przedziału. Warto jednak zauważyć, że zwiększanie próby w coraz mniejszym stopniu przekłada się na zmniejszanie szerokości przedziału.

\section{Przedziałowa estymacja wartości zagrożonej}

Estymacja wartości zagrożonej oraz oczekiwanego niedoboru jest zwykle estymacją punktową, czyli wynikiem jest konkretna wartość liczbowa. Warto zauważyć, iż w wypadku rozkładu ciągłego prawdopodobieństwo, że ocena punktowa parametru przyjmie wartość równą wartości szacowanego parametru, jest równe zero (Wawrzynek 2007). Alternatywnym rozwiązaniem jest estymacja przedziałowa, w której oceną parametru nie jest konkretna wartość, ale pewien przedział, do jakiego z określonym prawdopodobieństwem należy szacowana wartość parametru (Ostasiewicz, Rusnak i Siedlecka 2011). Podstawowym poję- 
ciem dotyczącym estymacji przedziałowej jest przedział ufności. Można go zdefiniować jako taki przedział $\left(\theta_{1}, \theta_{2}\right)$, który spełnia następujący warunek:

$$
P\left(\theta_{1}<\theta<\theta_{2}\right)=1-\alpha,
$$

gdzie 1 - $\alpha$ nazywane jest współczynnikiem ufności. Im wartość tego współczynnika jest większa, tym szerszy jest przedział ufności, a więc mniejsza dokładność estymacji parametru. Im wartość $1-\alpha$ jest mniejsza, tym większa jest dokładność estymacji, ale również tym większe prawdopodobieństwo popełnienia błędu. Wybór odpowiedniego współczynnika decyduje więc o dokładności estymacji (wielkości ryzyka błędu), wiąże się zatem z koniecznością pójścia na pewien kompromis. W praktyce przyjmuje się zazwyczaj wartości: 0,99, 0,95 lub 0,90, zależnie od parametru.

W wypadku estymacji wartości zagrożonej lub oczekiwanego niedoboru estymacja przedziałowa może być przydatnym narzędziem do analizy ryzyka modelu, a w szczególności ryzyka błędów w oszacowaniu parametrów modelu powstałych w wyniku zastosowania nieprawidłowej metody estymacji lub skończonej długości próby $^{2}$. W literaturze przedmiotu przedstawiono dwa podejścia do estymacji przedziałów ufności dla miary VaR:

1) podejście asymptotyczne (Duan i in. 2004), w którym wykorzystuje się nierówność Rao-Cramera i wrażliwość (delta method),

2) podejście, w którym wykorzystuje się metodę bootstrapową (Christoffersen i Gonçalves 2005; Pascual, Romo i Ruiz 2006).

Pierwsze podejście można nazwać klasycznym, opiera się na asymptotycznej normalności rozkładów estymatorów. Zgodnie z tym założeniem:

$$
\begin{gathered}
\operatorname{VaR}_{t}^{q} \sim N\left(\operatorname{VaR}_{t}^{q}, \delta_{t}^{2}\right), \\
\delta_{t}^{2}=\frac{\partial \operatorname{VaR} R_{t}}{\partial \theta^{\prime}} \Sigma \frac{\partial \operatorname{VaR} R_{t}}{\partial \theta}, \\
\Sigma=-\left[E \frac{\partial^{2} \ln L\left(\theta_{0}\right)}{\partial \theta \partial \theta^{\prime}}\right]^{-1},
\end{gathered}
$$

gdzie jako $\theta$ oznacza się zbiór parametrów modelu, a $\delta_{t}^{2}$ to zmienność rozkładu.

W drugim podejściu wykorzystuje się szereg pierwotny do estymacji parametrów modelu (np. modelu MGARCH), aby następnie oszacować standaryzowane reszty z modelu. W kolejnym kroku generowane są trajektorie procesu z wykorzystaniem oszacowanych wcześniej parametrów i reszt (w losowaniu ze zwra-

\footnotetext{
${ }^{2}$ Na podstawie wykładu nt. „Przedziałowa estymacja VaR i ES w modelach klasy AR-GARCH” wygłoszonego przez dra hab. Krzysztofa Piontka, prof. UE we Wrocławiu, podczas Seminarium Katedry Inwestycji Finansowych i Zarządzania Ryzykiem Uniwersytetu Ekonomicznego we Wrocławiu (Wrocław 2016).
} 
caniem). Dla każdej trajektorii estymowane są ponownie parametry modelu oraz wartość zagrożona. Gdy liczba trajektorii jest wystarczająca, możliwe jest oszacowanie przedziału dla wartości zagrożonej. Metodę tę można również zastosować do oszacowania przedziału ufności dla niedoboru oczekiwanego.

Dla jednowymiarowego szeregu czasowego $r_{t}$, przy założeniu, że model AR-GARCH ma następującą postać:

$$
r=\mu_{t}\left(\theta_{1}\right)+\sqrt{h_{t}\left(\theta_{2}\right)} z_{t}\left(\theta_{3}\right),
$$

przedziałowa estymacja wartości zagrożonej może zostać przeprowadzona według następującego schematu:

1. Estymacja parametrów $\hat{\theta}_{1}, \hat{\theta}_{2}, \hat{\theta}_{3}$ modelu, np. poprzez wykorzystanie metody największej wiarygodności. Dla najprostszej postaci modelu AR-GARCH zbiorem parametrów będzie $\left(\hat{\mu}_{0}, \hat{\mu}_{1}, \hat{\omega}, \hat{\alpha}, \hat{\beta}, \hat{v}, \hat{\lambda}\right)$.

2. Oszacowanie reszt standaryzowanych dla $t=1,2, \ldots, T$ za pomocą następującego wzoru:

$$
\hat{z}_{t}=\frac{r_{t}-\hat{\mu}_{t}}{\sqrt{\hat{h}_{t}}}
$$

gdzie:

$\hat{\mu}_{t}-$ warunkowa wartość oczekiwana,

$\hat{h}_{t}$ - warunkowa wariancji.

Przy założeniu, że zostanie zastosowany model AR-GARCH, wartości te będą oszacowywane w następujący sposób:

$$
\hat{\mu}_{t}=\hat{\mu}_{0}+\hat{\mu}_{1} r_{t-1} \text {, }
$$

gdzie: $r_{t-1}$ - stopa zwrotu z poprzedniego okresu,

$$
\begin{gathered}
\hat{h}_{t}=\hat{\omega}+\hat{\alpha}\left(r_{t-1}-\hat{\mu}_{t-1}\right)^{2}+\hat{\beta} \hat{h}_{t-1}, \\
\hat{h}_{1}=\frac{\hat{\omega}}{1-\hat{\alpha}-\hat{\beta}} .
\end{gathered}
$$

3. Generowanie szeregu danych poprzez losowanie ze zwracaniem ze standaryzowanych reszt $z_{t}^{*(i)}$, będących następnie podstawą do generowania trajektorii procesu AR-GARCH o parametrach $\hat{\theta}_{1}, \hat{\theta}_{2}, \hat{\theta}_{3}$ :

$$
\begin{gathered}
\left\{r_{1}^{*(i)}, \ldots, r_{T}^{*(i)}\right\}_{i=1, \ldots, B}, \\
r_{1}^{*(i)}=\hat{\mu}_{0}+\hat{\mu}_{1} r_{t-1}^{*(i)}+\sqrt{\hat{h}_{t}^{*(i)}} z_{t}^{*(i)}, \\
\hat{h}_{t}^{*(i)}=\hat{\omega}+\hat{\alpha}\left(r_{t-1}^{*(i)}-\hat{\mu}_{t-1}^{*(i)}\right)^{2}+\hat{\beta} \hat{h}_{t-1}^{*(i)} .
\end{gathered}
$$

4. Ponowna estymacja parametrów $\hat{\theta}_{1}^{*(i)}, \hat{\theta}_{2}^{*(i)}, \hat{\theta}_{3}^{*(i)}$ dla każdej wygenerowanej trajektorii. 
5. Wyznaczanie prognozy zmienności, kwantylu rozkładu oraz wartości zagrożonej dla każdego zbioru parametrów $\hat{\theta}_{1}^{*(i)}, \hat{\theta}_{2}^{*(i)}, \hat{\theta}_{3}^{*(i)}$.

Wyznaczanie na podstawie oszacowań VaR dystrybuanty empirycznej oraz przedziału ufności, co można przedstawić za pomocą równań:

$$
\begin{gathered}
\left\{\operatorname{VaR}_{T+1}^{q(1)}, \ldots, \operatorname{VaR_{T+1}^{q(B)}\} },\right. \\
Q_{\text {VaR }}^{*}(x)=\frac{\#\left\{\operatorname{VaR}_{T+1}^{q(1)} \leq x\right\}}{B}, \\
{\left[q_{\frac{\gamma}{2}}\left(Q_{\text {VaR }}^{*}(x)\right), q_{1-\frac{\gamma}{2}}\left(Q_{V a R}^{*}(x)\right)\right] .}
\end{gathered}
$$

Przedstawione podejście powinno być traktowane jako uzupełnienie estymacji punktowej przeprowadzanej w celu analizy błędu oszacowania wartości zagrożonej. Na błąd estymacji miary ryzyka ma wpływ zarówno błąd estymacji parametrów modelu, jak i kwantylu rozkładu warunkowego. Może być ono szczególnie przydatne podczas stosowania bardziej złożonych wielowymiarowych modeli, kiedy liczebność próby jest ograniczona, ponieważ w takich sytuacjach niezwykle istotna jest analiza ryzyka błędu estymacji. Podczas przeprowadzania procedury ważne jest odpowiednie dobranie długości próby: dopasowanie jej do długości próby dostępnych danych finansowych.

\section{Miara ryzyka estymacji parametrów modelu VaR}

Rozkład prognoz VaR, będący podstawą do oszacowania przedziału ufności, został przygotowany z wykorzystaniem metody bootstrapowej (Christoffersen i Gonçalves 2005, Pascual, Romo i Ruiz 2006). W przeprowadzonych badaniach wykorzystano współczynnik ufności na poziomie 0,95 . Na podstawie górnej i dolnej granicy przedziału $\left(\theta_{1}<\theta<\theta_{2}\right)$ obliczane są dwa szeregi przekroczeń, co można opisać za pomocą następujących wzorów:

$$
\begin{aligned}
& I_{t, \theta_{1}}=\left\{\begin{array}{l}
1, r_{t+1}<-V a R_{r, t, \theta_{1}}, \\
0, r_{t+1} \geq-V a R_{r, t, \theta_{1}}
\end{array}\right. \\
& I_{t, \theta_{2}}=\left\{\begin{array}{l}
1, r_{t+1}<-V a R_{r, t, \theta_{2}} \\
0, r_{t+1} \geq-V a R_{r, t, \theta_{2}}
\end{array} .\right.
\end{aligned}
$$

Wykorzystując szereg przekroczeń, można obliczyć następujący przedział:

$$
\left(\frac{\sum_{i=1}^{T} I_{t, \theta_{1}}}{T}<\frac{\sum_{i=1}^{T} I_{t}}{T}<\frac{\sum_{i=1}^{T} I_{t, \theta_{2}}}{T}\right),
$$

gdzie: $T$ - liczba wszystkich obserwacji. 
Szerokość przedziału określona jest wzorem:

$$
\theta^{*}=\left(\frac{\sum_{i=1}^{T} I_{t, \theta_{1}}}{T}-\frac{\sum_{i=1}^{T} I_{t, \theta_{2}}}{T}\right) .
$$

Tak obliczona szerokość przedziału jest porównywana do szerokości przedziału liczby przekroczeń, która zgodnie z testem Kupca nie daje podstaw do odrzucenia modelu. Współczynnik jest obliczany zgodnie ze wzorem:

$$
\delta=\frac{\left(\frac{\sum_{i=1}^{T} I_{t, \theta_{1}}}{T}-\frac{\sum_{i=1}^{T} I_{t, \theta_{2}}}{T}\right)}{\frac{x_{\max }}{T}-\frac{x_{\min }}{T}} .
$$

lub też w uproszczonej formie:

$$
\delta=\frac{\left(\sum_{i=1}^{T} I_{t, \theta_{1}}-\sum_{i=1}^{T} I_{t, \theta_{2}}\right)}{x_{\max }-x_{\min }},
$$

gdzie:

$x_{\min }$ - minimalna liczba przekroczeń zapewniająca akceptację modelu zgodnie $\mathrm{z}$ testem Kupca,

$x_{\max }$ - maksymalna liczba przekroczeń zapewniająca akceptację modelu zgodnie $\mathrm{z}$ testem Kupca.

Miarę $\delta$ zdefiniowano więc jako iloraz przedziałowej estymacji VaR (wykorzystano współczynnik ufności na poziomie 0,95) oraz szerokości przedziału wartości zagrożonej wynikającej z minimalnej i maksymalnej liczby przekroczeń dla danego poziomu tolerancji i wielkości prób, aby model nie został odrzucony na podstawie wyników testu Kupca. Przedziałowa estymacja VaR została przeprowadzona zgodnie z podejściem, w którym wykorzystuje się metodę bootstrapową, zastosowaną przez P.F. Christoffersena i S. Gonçalves (2005) oraz L. Pascuala, J. Roma i E. Ruiz (2006). Im wartość zaproponowanego współczynnika jest mniejsza, tym większą precyzję wykazuje model. Wysoka wartość wskaźnika może oznaczać, że ryzyko estymacji parametrów modelu jest znaczne, zweryfikowanie modelu za pomocą testów statystycznych nie powinno wówczas być podstawą do jego wdrożenia.

\section{Badania empiryczne}

W ramach przykładu obrazującego zastosowanie zaproponowanej miary ryzyka modelu przeprowadzono badania na danych historycznych z portfela składającego się z siedmiu instrumentów: trzech instrumentów z rynku towarowego (kontraktów terminowych na złoto, srebro, ropę naftową typu brent), trzech 
par walutowych związanych z dolarem amerykańskim (EURUSD, USDGBP, USDJPY) oraz kontraktu na 10-letnie obligacje emitowane przez Stany Zjednoczone. Badanie zostało przeprowadzone na danych z okresu od 14 czerwca $1996 \mathrm{r}$. do 15 lipca 2016 r. (z 5000 sesji giełdowych). Podzielono je na próbę uczącą się oraz testową dla pierwszej prognozy w następujący sposób: dane dotyczące okresu od 14 czerwca 1996 r. do 28 kwietnia 2008 r. (3000 sesji giełdowych) stanowiły początkową próbę uczącą, a dane dotyczące okresu od 30 kwietnia 2008 r. do 15 lipca 2016 r. (2000 sesji giełdowych) - próbę testową, dla której sporządzono prognozy wartości zagrożonej. Na rys. 2 przedstawiono proste stopy zwrotu $\mathrm{z}$ otrzymanego portfela.

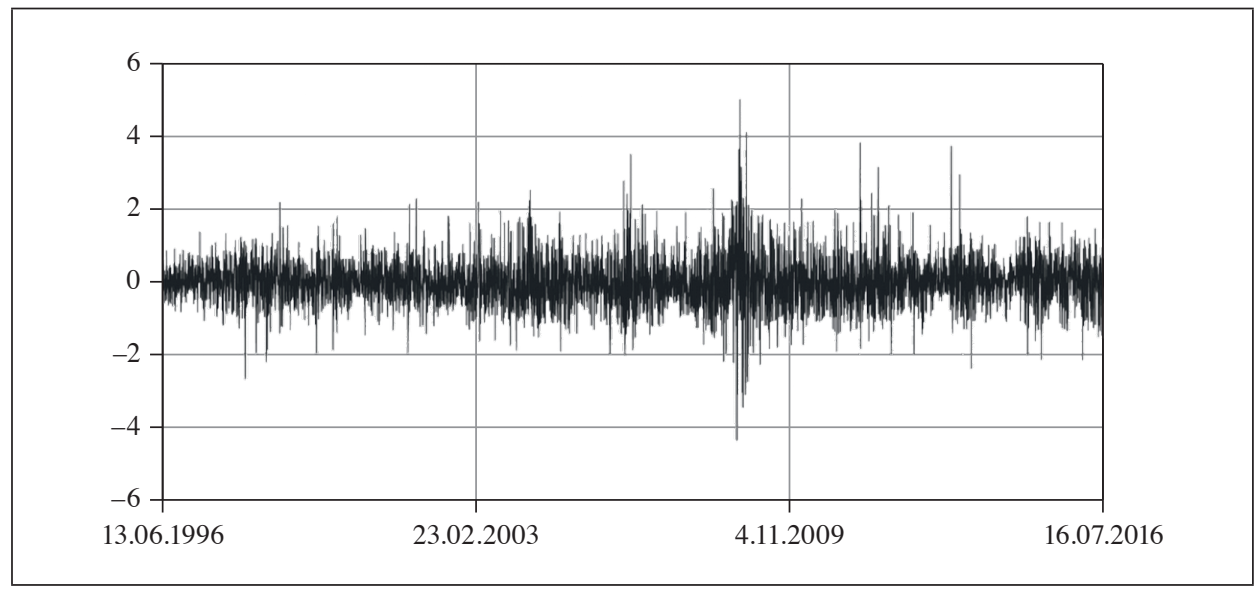

Rys. 2. Proste stopy zwrotu z portfela 7-składnikowego o równych wagach Źródło: opracowanie własne.

Analizie poddano trzy modele:

- model wartości zagrożonej, w którym wykorzystano rozkład normalny (metodę wariancji i kowariancji) (Rokita 2004),

- model wartości zagrożonej z wykorzystaniem modelu AR-GARCH - założono warunkową macierzy kowariancji (Bollerslev 1987) oraz rozkład normalny jako rozkład reszt,

- model wartości zagrożonej, w którym wykorzystano model SV (stochastic volatility) - w tym wypadku również założono warunkową macierzy kowariancji (Taylor 1994) oraz rozkład normalny jako rozkład reszt.

W przedstawionym przykładzie analizowano jedynie wartość zagrożoną z przedziałem ufności 0,95 . W pierwszej kolejności na podstawie sporządzonych prognoz wartości zagrożonej zostały przeprowadzone testy szeregu przekroczeń, m.in. test Kupca (Kupiec 1995), test Christoffersena (Christoffersen 1998), test 
LR (Campbell 2005). Dla każdego modelu obliczono dodatkowo wartość trzech funkcji straty: funkcji Lopeza (Lopez 1998), Mohameda (Mohamed 2005), Sarmy-Thomas-Shaha (Sarma, Thomas i Shah 2003), oraz przeprowadzono testy zgodności empirycznego rozkładu reszt z modelu z założonym: testy Ljunga-Boksa (test niezależności reszt), Engle'a (Engle 1982) - efekt ARCH - lub Pearsona (test zgodności rozkładu).

Wyniki przeprowadzonych badań przedstawiono w tabelach 2-4. Warto podkreślić, że model, w którym założono proces stochastycznej wariancji SV, wypadł źle jedynie w testach Engle’a i Pearsona - podczas przeprowadzenia pozostałych testów nie było podstaw do odrzucenia tego modelu. Pozostałe modele powinny zostać odrzucone na podstawie testu LR. Jeżeli do wyboru właściwego modelu zostały zastosowane jedynie testy statystyczne, to jako najlepszy powinien zostać wybrany właśnie model stochastycznej wariancji, estymowany zgodnie z podejściem bayesowskim.

Tabela 2. Miary i kryteria oceny modelu

\begin{tabular}{|c|c|c|c|c|}
\hline \multicolumn{2}{|c|}{ Wyszczególnienie } & $\begin{array}{l}\text { Wielowymiarowy } \\
\text { rozkład normalny }\end{array}$ & AR-GARCH & SV \\
\hline \multicolumn{2}{|c|}{ Współczynnik ufności } & 0,95 & 0,95 & 0,95 \\
\hline \multirow{4}{*}{ Przekroczenia } & próba & 2001 & 2001 & 2001 \\
\hline & liczba przekroczeń & 105 & 108 & 116 \\
\hline & $\begin{array}{l}\text { procentowy udział } \\
\text { przekroczeń }\end{array}$ & 5,25 & 5,40 & 5,80 \\
\hline & $\begin{array}{l}\text { oczekiwana liczba } \\
\text { przekroczeń }\end{array}$ & 100 & 100 & 100 \\
\hline \multirow{3}{*}{ Test Kupca } & $\begin{array}{l}\text { wartość statystyki } \\
\text { testowej }\end{array}$ & 0,25 & 0,65 & 2,55 \\
\hline & $p$-value & 0,6144 & 0,4205 & 0,1102 \\
\hline & wynik testu & $\begin{array}{l}\text { brak podstaw } \\
\text { do odrzucenia }\end{array}$ & $\begin{array}{l}\text { brak podstaw } \\
\text { do odrzucenia }\end{array}$ & $\begin{array}{l}\text { brak podstaw } \\
\text { do odrzucenia }\end{array}$ \\
\hline \multirow{3}{*}{$\begin{array}{l}\text { Test Chris- } \\
\text { tofersena }\end{array}$} & $\begin{array}{l}\text { wartość statystyki } \\
\text { testowej }\end{array}$ & 1,11 & 0,25 & 0,26 \\
\hline & $p$-value & 0,2915 & 0,6190 & 0,6120 \\
\hline & wynik testu & $\begin{array}{l}\text { brak podstaw } \\
\text { do odrzucenia }\end{array}$ & $\begin{array}{l}\text { brak podstaw } \\
\text { do odrzucenia }\end{array}$ & $\begin{array}{l}\text { brak podstaw } \\
\text { do odrzucenia }\end{array}$ \\
\hline \multirow{3}{*}{ Test LR } & statystyka & 176,40 & 142,55 & 140,09 \\
\hline & $p$-value & 0,0000 & 0,0145 & 0,0634 \\
\hline & wynik testu & odrzucenie & odrzucenie & $\begin{array}{l}\text { brak podstaw } \\
\text { do odrzucenia }\end{array}$ \\
\hline
\end{tabular}

Źródło: opracowanie własne. 
Tabela 3. Funkcje straty

\begin{tabular}{|c|l|c|c|c|}
\hline \multicolumn{2}{|c|}{ Wyszczególnienie } & $\begin{array}{c}\text { Wielowymiarowy } \\
\text { rozkład normalny }\end{array}$ & $\begin{array}{c}\text { AR(1)- } \\
\text {-GARCH(1,1) }\end{array}$ & SV \\
\hline \multirow{2}{*}{ Współczynnik ufności } & 0,95 & 0,95 & 0,95 \\
\hline \multirow{3}{*}{ Funkcje straty } & Lopez & 0,0525 & 0,0540 & 0,0580 \\
\cline { 2 - 5 } & Mohamed & 0,0411 & 0,0229 & 0,0251 \\
\cline { 2 - 5 } & Sarma-Thomas-Shah & 0,0042 & 0,0042 & 0,0041 \\
\hline
\end{tabular}

Źródło: opracowanie własne.

Tabela 4. Testy zgodności empirycznego rozkładu reszt z modelu z założonym

\begin{tabular}{|c|c|c|c|c|}
\hline \multicolumn{2}{|c|}{ Wyszczególnienie } & $\begin{array}{l}\text { Wielowymiarowy } \\
\text { rozkład normalny }\end{array}$ & AR-GARCH & SV \\
\hline \multicolumn{2}{|l|}{ Próba } & 5000 & 5000 & 5000 \\
\hline \multirow{2}{*}{$\begin{array}{l}\text { Test Ljunga-Boksa } \\
\text { (1 opóźnienie) }\end{array}$} & $p$-value & 0,7227 & 0,2974 & 0,2398 \\
\hline & wynik testu: & $\begin{array}{l}\text { brak podstaw } \\
\text { do odrzucenia }\end{array}$ & $\begin{array}{l}\text { brak podstaw } \\
\text { do odrzucenia }\end{array}$ & $\begin{array}{l}\text { brak podstaw } \\
\text { do odrzucenia }\end{array}$ \\
\hline \multirow{2}{*}{$\begin{array}{l}\text { Test Ljunga-Boksa } \\
\text { ( } 2 \text { opóźnienia) }\end{array}$} & $p$-value & 0,9191 & 0,3959 & 0,4798 \\
\hline & wynik testu & $\begin{array}{l}\text { brak podstaw } \\
\text { do odrzucenia }\end{array}$ & $\begin{array}{l}\text { brak podstaw } \\
\text { do odrzucenia }\end{array}$ & $\begin{array}{l}\text { brak podstaw } \\
\text { do odrzucenia }\end{array}$ \\
\hline \multirow{2}{*}{$\begin{array}{l}\text { Test Ljunga-Boksa } \\
\text { ( } 5 \text { opóźnień) }\end{array}$} & $p$-value & 0,6167 & 0,1818 & 0,3056 \\
\hline & wynik testu & $\begin{array}{l}\text { brak podstaw } \\
\text { do odrzucenia }\end{array}$ & $\begin{array}{l}\text { brak podstaw } \\
\text { do odrzucenia }\end{array}$ & $\begin{array}{l}\text { brak podstaw } \\
\text { do odrzucenia }\end{array}$ \\
\hline \multirow{2}{*}{$\begin{array}{l}\text { Test Ljunga-Boksa } \\
\text { (10 opóźnień) }\end{array}$} & $p$-value & 0,9036 & 0,4565 & 0,5768 \\
\hline & wynik testu & $\begin{array}{l}\text { brak podstaw } \\
\text { do odrzucenia }\end{array}$ & $\begin{array}{l}\text { brak podstaw } \\
\text { do odrzucenia }\end{array}$ & $\begin{array}{l}\text { brak podstaw } \\
\text { do odrzucenia }\end{array}$ \\
\hline \multirow{2}{*}{$\begin{array}{l}\text { Test Engle’a } \\
\text { (1 opóźnienie) }\end{array}$} & $p$-value & $3,35 \mathrm{E}-11$ & 0,3910 & 0,0021 \\
\hline & wynik testu & odrzucenie & $\begin{array}{l}\text { brak podstaw } \\
\text { do odrzucenia }\end{array}$ & odrzucenie \\
\hline \multirow{2}{*}{$\begin{array}{l}\text { Test Engle'a } \\
\text { (2 opóźnienia) }\end{array}$} & $p$-value & 0,0000 & 0,0338 & 0,0005 \\
\hline & wynik testu & odrzucenie & odrzucenie & odrzucenie \\
\hline \multirow{2}{*}{$\begin{array}{l}\text { Test Engle’a } \\
\text { (5 opóźnień) }\end{array}$} & $p$-value & 0,0000 & 0,0035 & 0,0000 \\
\hline & wynik testu & odrzucenie & odrzucenie & odrzucenie \\
\hline \multirow{2}{*}{$\begin{array}{l}\text { Test Engle'a } \\
\text { (10 opóźnień) }\end{array}$} & $p$-value & 0,0000 & 0,0018 & 0,0000 \\
\hline & wynik testu & odrzucenie & odrzucenie & odrzucenie \\
\hline \multirow{2}{*}{ Test Pearsona } & $p$-value & $6,67 \mathrm{E}-17$ & 0,0000 & 0,0180 \\
\hline & wynik testu & odrzucenie & odrzucenie & odrzucenie \\
\hline
\end{tabular}

Źródło: opracowanie własne. 
W następnej kolejności oszacowano wartości parametru $\delta$, który zgodnie z przedstawionymi rozważaniami można zinterpretować jako relację empirycznego rozstępu przekroczeń obliczonego na podstawie przedziałowej estymacji VaR do szerokości przedziału zdeterminowanego przez statystykę testu Kupca. W tabeli 5 zaprezentowano wyniki pomiaru ryzyka estymacji parametrów. Parametr $\delta$ jest znacznie wyższy dla modelu SV, ponieważ zakłada się, że proces wariancji również zawiera element losowy oraz że procedura estymacji jest bardziej skomplikowana ze względu na konieczność wykonania wielu symulacji. W wypadku dwóch pozostałych metod wariancja, na podstawie której sporządzana jest prognoza wartości zagrożonej, jest albo stała, albo jest procesem deterministycznym.

Tabela 5. Pomiar ryzyka estymacji parametrów

\begin{tabular}{|c|c|c|c|c|}
\hline \multicolumn{2}{|c|}{ Wyszczególnienie } & $\begin{array}{l}\text { Wielowymiarowy } \\
\text { rozkład normalny }\end{array}$ & $\begin{array}{c}\text { AR(1)- } \\
\text {-GARCH(1,1) }\end{array}$ & SV \\
\hline \multicolumn{2}{|c|}{ Współczynnik ufności } & 0,95 & 0,95 & 0,95 \\
\hline \multirow{4}{*}{ Przekroczenia } & próba & 2001 & 2001 & 2001 \\
\hline & liczba przekroczeń & 105 & 108 & 116 \\
\hline & $\begin{array}{l}\text { procentowy udział } \\
\text { przekroczeń }\end{array}$ & 5,25 & 5,40 & 5,80 \\
\hline & $\begin{array}{l}\text { oczekiwana liczba } \\
\text { przekroczeń }\end{array}$ & 100 & 100 & 100 \\
\hline \multirow{7}{*}{$\begin{array}{l}\text { Estymacja } \\
\text { przedziałowa }\end{array}$} & $\begin{array}{l}\text { przekroczenia } \\
\text { (niedoszacowanie) }\end{array}$ & 110 & 120 & 227 \\
\hline & $\begin{array}{l}\text { procentowy udział } \\
\text { przekroczeń }\end{array}$ & 5,50 & 6,00 & 11,34 \\
\hline & $\begin{array}{l}\text { przekroczenia } \\
\text { (przeszacowanie) }\end{array}$ & 99 & 102 & 53 \\
\hline & $\begin{array}{l}\text { procentowy udział } \\
\text { przekroczeń }\end{array}$ & 4,95 & 5,10 & 2,65 \\
\hline & $\begin{array}{l}\text { średnia szerokość } \\
\text { standaryzowanego } \\
\text { przedziału }\end{array}$ & 0,1131 & 0,0596 & 0,9279 \\
\hline & $\begin{array}{l}\mathrm{T} \times \theta^{*} \text { (liczba prze- } \\
\text { kroczeń) }\end{array}$ & 11 & 18 & 174 \\
\hline & $\delta$ & 0,29 & 0,47 & 4,55 \\
\hline
\end{tabular}

Źródło: opracowanie własne.

Po przeanalizowaniu wyników można stwierdzić, że mimo iż model SV, który dobrze wypadał w klasycznych testach VaR, daje zadowalające prognozy, możliwy do zaakceptowania jest także model AR-GARCH. Miara $\delta$ jest w tym wypadku 
niewiele większa niż w wypadku prostego modelu opartego na wielowymiarowym rozkładzie normalnym i znacznie mniejsza niż w wypadku modelu stochastycznej wariancji. $\delta$ o wartości 4,55 oznacza, że szerokość estymacji przedziałowej jest prawie pięciokrotnie większa niż przedział wyznaczony na podstawie przeprowadzenia testu Kupca. Oznacza to, że błąd wynikający z ograniczonej próby i postaci modelu jest tak duży, iż zastosowanie klasycznych testów statystycznych podczas analizy szeregu przekroczeń daje mało wiarygodne wyniki. Dodatkowo w modelu AR-GARCH uwzględnia się autokorelacje kwadratów reszt, co potwierdzają wyniki testu Engle’a, niższe są także wartości funkcji straty - niskie wartości funkcji straty świadczą o dobrym dopasowaniu modelu.

\section{Zakończenie}

Ryzyko estymacji modelu w finansach jest szczególnie istotne m.in. ze względu na ograniczoną liczbę danych historycznych. Modele pomiaru ryzyka stosowane w praktyce nie powinny być bardziej złożone, niż to potrzebne, np. nie powinny mieć zbyt dużej liczby parametrów. Parametry tych modeli nie mogą być także zbyt trudne do estymacji. Stosowanie się do tych zasad służy ograniczeniu ryzyka estymacji parametrów. Błąd w oszacowaniu parametrów, oprócz tego, że może wynikać ze skończonej długości próby, może również być skutkiem przyjęcia nieprawidłowej metody estymacji (np. wykorzystania metody nieuwzględniającej występowania obserwacji nietypowych lub dokonania estymacji parametrów nieuwzględniających niestacjonarności szeregów czasowych). Z tego względu należy zweryfikować model w momencie tworzenia go i przeprowadzić wówczas analizę ryzyka modelu.

Celem pracy było zaproponowanie miary ryzyka estymacji parametrów modelu wartości zagrożonej na podstawie estymacji przedziałowej. Miarę $\delta$ zdefiniowano jako iloraz przedziałowej estymacji VaR (wykorzystano współczynnik ufności na poziomie 0,95 ) oraz szerokości przedziału wartości zagrożonej, wynikający z minimalnej i maksymalnej liczby przekroczeń dla zadanego poziomu tolerancji i wielkości prób niepowodujących odrzucenia modelu na podstawie testu Kupca. Przedziałowa estymacja VaR została przeprowadzona zgodnie z podejściem, w którym wykorzystuje się metodę bootstrapową, zastosowaną przez P.F. Christoffersena i S. Gonçalves (2005) oraz L. Pascuala, J. Roma i E. Ruiz (2006).

Im wartość zaproponowanego współczynnika była mniejsza, tym większą precyzję wykazywał model. Duża wartość wskaźnika może oznaczać, że ryzyko estymacji parametrów modelu jest znaczne, samo przeprowadzenie testów nie powinno więc być podstawą do wdrożenia modelu. Im większa jest długość szeregu przekroczeń (im większa próba wykorzystana do testu), tym mniejsza 
jest szerokość przedziału, w którym powinna się mieścić liczba przekroczeń, przy założeniu, że wybrany model prawidłowo odzwierciedla badane zjawisko. Miarę można zastosować również do wyznaczania liczby danych historycznych niezbędnej do poprawnego przeprowadzenia walidacji modelu. $\mathrm{Z}$ tego względu dalsze badania związane $\mathrm{z}$ tematyką przedstawioną $\mathrm{w}$ pracy będą dotyczyły zaprojektowania metody ułatwiającej dobór właściwej próby w zależności od maksymalnego poziomu ryzyka estymacji parametrów modelu.

\section{Literatura}

Best P. (2005), Wartość narażona na ryzyko. Obliczanie i wdrażanie modelu VaR, Dom Wydawniczy ABC, Kraków.

Bollerslev T. (1987), A Conditionally Heteroskedastic Time Series Model for Speculative Prices and Rates of Return, ,The Review of Economics and Statistics”, vol. 69, nr 3, https://doi.org/10.2307/1925546.

Campbell S.D. (2005), A Review of Backtesting and Backtesting Procedures, Finance and Economics Discussion Series Divisions of Research \& Statistics and Monetary Affairs Federal Reserve Board No 2005-21, Washington, DC.

Christoffersen P.F. (1998), Evaluating Interval Forecasts, „International Economic Review", vol. 39, nr 4, https://doi.org/10.2307/2527341.

Christoffersen P.F., Gonçalves S. (2005), Estimation Risk in Financial Risk Management, „Journal of Risk”, vol. 7, nr 3, https://doi.org/10.21314/jor.2005.112.

Doman M., Doman R. (2009), Modelowanie zmienności i ryzyka. Metody ekonometrii finansowej, Wolters Kluwer, Kraków.

Dowd K. (2006), Retrospective Assessment of Value at Risk (w:) Risk Management: A Modern Perspective, red. M.K. Ong, Elsevier, San Diego.

Duan J.Ch., Simonato J.G., Gauthier G., Zaanoun S. (2004), Estimating Merton's Model by Maximum Likelihood with Survivorship Consideration, EFA 2004 Maastricht Meetings Paper No 4190, https://doi.org/10.2139/ssrn.557088.

Engle R.F. (1982), Autoregressive Conditional Heteroscedasticity with Estimates of the Variance of United Kingdom Inflation, „Econometrica”, vol. 50, $\mathrm{nr} 4$, https://doi. org/10.2307/1912773.

Jajuga K. (2001), Value at Risk, „Rynek Terminowy”, nr 13.

Jajuga K. (2013), Ryzyko modelu a miary ryzyka, ,Studia Ekonomiczne. Zeszyty Naukowe Uniwersytetu Ekonomicznego w Katowicach", nr 53.

Kupiec P.H. (1995), Techniques for Verifying the Accuracy of Risk Measurement Models, „The Journal of Derivatives”, vol. 3, nr 2, https://doi.org/10.3905/jod.1995.407942.

Kuziak K. (2011), Pomiar ryzyka przedsiębiorstwa. Modele pomiaru i ich ryzyko, Wydawnictwo Uniwersytetu Ekonomicznego we Wrocławiu, Wrocław.

Lopez J. (1998), Methods for Evaluating Value-at-Risk Estimates, „Economic Policy Review", October.

Mohamed A.R. (2005), Would Student's t-GARCH Improve VaR Estimates?, University of Jyväskylä, www.gloriamundi.org (data dostępu: 25.05.2017).

Ostasiewicz S., Rusnak Z., Siedlecka U. (2011), Statystyka. Elementy teorii i zadania, Wydawnictwo Uniwersytetu Ekonomicznego we Wrocławiu, Wrocław. 
Pascual L., Romo J., Ruiz E. (2006), Bootstrap Prediction for Returns and Volatilities in GARCH Models, „Computational Statistics \& Data Analysis”, vol. 50, nr 9, https://doi. org/10.1016/j.csda.2004.12.008.

Piontek K. (2007), Przeglqd i porównanie metod oceny modeli VaR (w:) Matematyczne $i$ ekonometryczne metody oceny ryzyka finansowego, red. P. Chrzan, Prace Naukowe, Akademia Ekonomiczna w Katowicach, Wydawnictwo Akademii Ekonomicznej w Katowicach, Katowice.

Rokita P. (2004), Koncepcja wartości zagrożonej (VaR) w analizie ryzyka inwestycji banków na rynku polskim, praca doktorska, Uniwersytet Ekonomiczny we Wrocławiu, Wrocław.

Sarma M., Thomas S., Shah A. (2003), Selection of Value-at-Risk Models, ,Journal of Forecasting", vol. 22, nr 4, ideas.repec.org/s/jof/jforec.html (data dostępu: 25.05.2017).

Taylor S.J. (1994), Modeling Stochastic Volatility: A Review and Comparative Study, „Mathematical Finance”, vol. 4, nr 2, https://doi.org/10.1111/j.1467-9965.1994.tb00057.x.

Wawrzynek J. (2007), Metody opisu i wnioskowania statystycznego, Wydawnictwo Akademii Ekonomicznej im. Oskara Langego we Wrocławiu, Wrocław.

Zarzqdzanie ryzykiem (2008), red. K. Jajuga, Wydawnictwo Naukowe PWN, Warszawa.

\section{Model Risk for Value at Risk}

(Abstract)

Value at risk is one of the most common measures of financial risk. There are many approaches to validating value-for-value models. In addition to ex post tests, ex ante models must also be validated. The risk of model estimation is particularly important in finance due to the limited number of historical data that is available to estimate the parameters. The aim of this paper is to propose a measure of the risk of estimating the VaR model based on the interval of the value at risk.

Keywords: value at risk, interval estimation, model risk, estimation risk of model parameters. 